\title{
Effect of Initial Cracking and Bitumen Coating on Performance of Concrete in Sulfate Environment
}

\author{
Roz-Ud-Din Nassar,", Taqdees Aysha ${ }^{2}$, Safeer Abbas ${ }^{3}$, Danish Saeed $^{4}$ \\ ${ }^{1}$ Department of Civil and Infrastructure Engineering, American University of Ras Al Khaimah (AURAK), Ras Al Khaimah, \\ United Arab Emirates (UAE) \\ ${ }^{2}$ Concrete Technology L.L.C, Ras Al Khaimah, United Arab Emirates (UAE) \\ ${ }^{3}$ Department of Civil Engineering, University of Engineering and Technology Lahore, Pakistan \\ ${ }^{4}$ Khwaja Fareed University of Engineering and Information Technology (KFUEIT), Rahim Yar Khan, Pakistan
}

Received June 20, 2021; Revised August 9, 2021; Accepted September 8, 2021

\section{Cite This Paper in the following Citation Styles}

(a): [1] Roz-Ud-Din Nassar, Taqdees Aysha, Safeer Abbas, Danish Saeed, "Effect of Initial Cracking and Bitumen Coating on Performance of Concrete in Sulfate Environment," Civil Engineering and Architecture, Vol. 9, No. 6, pp. 1846-1853, 2021. DOI: 10.13189/cea.2021.090617.

(b): Roz-Ud-Din Nassar, Taqdees Aysha, Safeer Abbas, Danish Saeed (2021). Effect of Initial Cracking and Bitumen Coating on Performance of Concrete in Sulfate Environment. Civil Engineering and Architecture, 9(6), 1846-1853. DOI: 10.13189/cea.2021.090617.

Copyright $\odot 2021$ by authors, all rights reserved. Authors agree that this article remains permanently open access under the terms of the Creative Commons Attribution License 4.0 International License

\begin{abstract}
Sulfate attack on concrete is considered to be one of the major durability issues. It results in major deterioration of concrete and ultimate failure of the concrete structural members. Mainly, sulfate attack is caused by the transport of sulfate ions from outside source into concrete. Sulfate attack usually manifests in the form of expansion and cracking of concrete. This study reports the strength and durability performances of cracked and uncracked plain and reinforced concrete specimens in sulfate environment induced by their exposure to various concentrations of sodium sulfate $\left(\mathrm{Na}_{2} \mathrm{SO}_{4}\right)$ solution over a period of 120 days. A variety of specimens produced with a standard concrete mixture having $\mathrm{w} / \mathrm{c}$ ratio of 0.47 were tested under aggressive sulfate environment. Physical testing including visual inspection and change in mass of the conditioned specimens was carried out at $7,14,28,56$, 90 and 120 days of exposure period to accelerated sulfate environment. Compressive strength of cylinder specimens and flexural strength of reinforced concrete prisms were also tested at the same ages. Test results showed that bitumen coating of concrete specimens enhanced their resistance to the deleterious effects of sulfate attack. It was further observed that the depth of efflorescence and change in mass of specimens was higher in the case of their exposure to higher concentrations of sulfate solution. The effect of exposure to sulfate solution was severe in the case of cracked specimens than the uncracked ones. The results
\end{abstract}

of this study provide insight into the performance characteristics of concrete in sulfate environment.

Keywords Sulfate Attack, Bitumen Coating, Mechanical Properties, Durability, Cracked Specimen

\section{Introduction}

Sulfate attack on concrete is one of the major durability issues of concrete, globally, which is triggered by the entry of sulfate ions $\left(\mathrm{SO}_{4}^{-2}\right)$ in concrete through physical or chemical means $[1,2]$. Sulfate ions may enter concrete when the latter is in contact with soil or water having higher concentration of sulfate. Seawater and industrial effluents are the other possible causes of supply of sulfate ions in concrete. However, one or more of the constituents of the concrete, such as aggregates or cement themselves, could also supply sulfate ions. The reaction of sulfate ions with calcium hydroxide $\left(\mathrm{Ca}(\mathrm{OH})_{2}\right)$ and the hydrates of tricalcium aluminate $\left(\mathrm{C}_{3} \mathrm{~A}\right)$ results in the formation of ettringite which is an expansive product and cracking of concrete [3-5]. The extent of degradation due to sulfate attack depends on various factors such as the permeability of concrete, water to cement ratio of the mix, and concentration and distribution of sulfate ions in concrete [6-9]. 
Extensive research has been carried out in past to assess the influence of sulfate attack on the strength and durability characteristics of concrete. It has been reported that a significant reduction in direct tensile strength of concrete with high $\mathrm{C}_{3} \mathrm{~A}$ content occurs when it is exposed to sodium sulfate solutions of varying concentration. Increased concentration of sulfates in solution has been observed to cause higher loss of tensile strength [10]. It has been found that the combined effect of freeze-thaw cycles and sulfate exposure severely undermines the compressive strength of concrete made with recycled aggregates [11]. Hussein, Luaay, et al [12] investigated the sulfate resistance of composite concrete members made with one layer of normal strength concrete bonded with another layer of high strength concrete reinforced with varying percentages of fibers. Although a large amount of ettringite was found in normal concrete layer, increased fiber content resulted in improved resistance against degradation. Bassuoni and Nehdi [13] suggested that lower concentration of sodium sulfate can be deleterious when accompanied by cycles of wetting and drying. So, if higher concentrations of sulfate ions are present during wetting-drying cycles, it can have damaging effects on concrete [14-16].

Various studies have been conducted to minimize the extent of distress caused by sulfate attack. Use of sulfate resisting cement is one of the possible solutions to the problem. ASTM C150 limits the amount of tricalcium aluminate $\left(\mathrm{C}_{3} \mathrm{~A}\right)$ in sulfate resisting cement to $5 \%$ but it may not always guarantee the required resistance of concrete against sulfate attack $[17,18]$. Many researchers have investigated the possibility of utilizing supplementary cementitious materials in enhancing the sulfate resistance of concrete structures. Dhole, Rajaram, et al. observed that a ternary combination of $15 \%$ and $10 \%$ class $\mathrm{C}$ and class $\mathrm{F}$ fly ash, respectively, along with $4 \%$ silica fume, showed improved sulfate resistance when subjected to 500 days of cyclic sodium sulfate and calcium sulfate exposure [19]. A unique microbial treatment for durability improvement of concrete was presented by Joshi, Sumit, et al. [20], which considers calcifying bacteria either mixed or sprayed on concrete and mortar specimens. Bacteria treated specimens exhibited excellent performance against both chemical and physical attack. Authors attributed this behavior to the densification of concrete matrix as a result of calcium carbonate precipitation. Presence of high concentrations of bicarbonates also results in the destabilization of gypsum and ettringite which ultimately lead to less or no expansion [21]. Replacement of cement by glass powder up to a level of $10 \%$ has been reported to be helpful in mitigating deleterious effects of exposure to magnesium sulfate [22]. Various studies suggested surface coating of members as an effective prevention technique of sulfate attack and other aggressive environments [23-26]. Polymer coatings are recommended as most effective surface treatment method against the penetration of aggressive salts [27].

In most of the previous studies, the influence of sulfate attack has been investigated on un-cracked concrete specimens. Since concrete has negligible tensile strength, cracks are always developed in concrete members at early stages of loading. The effect of sulfates on cracked concrete members may cause more severe damage due to easy access of sulfate ions to a greater depth inside the member. This research is carried out to simultaneously investigate the influence of sodium sulfate concentration, pre-cracking of reinforced concrete specimens, wetting-drying cycles, and bitumen coating on sulfate resistance of concrete. Mechanical performance is evaluated by compressive strength and flexural strength tests, whereas, mass change and depth of efflorescence were used in durability assessment of aged specimens.

\section{Experimental Program}

\subsection{Materials and Mix Design}

Concrete mixture having 28 days target compressive strength of $27 \mathrm{MPa}$ was manufactured using type-1 ordinary Portland cement, coarse and fine aggregates confirming to the relevant ASTM specifications and tap water confirming to ASTM C1602M. Physical characteristics of coarse and fine aggregates are provided in Table 1. Concrete mixture design used for the production of various specimens is presented in Table 2 . Grade 60 deformed steel bars of $10 \mathrm{~mm}$ diameter were used to reinforce the concrete beam specimens while maintaining a concrete cover of $20 \mathrm{~mm}$. Concrete mixture was manufactured with a slightly higher water-to-cement ratio of 0.47 to help accelerate the sulfate attack mechanism.

\subsection{Preparation and Curing of Samples}

Concrete cylinders and prisms were prepared in accordance with relevant ASTM standards. To perform the compressive strength 54 concrete cylinders of $150 \mathrm{~mm}$ diameter and $300 \mathrm{~mm}$ height were prepared according to ASTM C192. A total of 90 reinforced concrete beams having $100 \mathrm{~mm} \times 100 \mathrm{~mm}$ cross section and $500 \mathrm{~mm}$ length were prepared to evaluate the flexural strength of concrete. Concrete ingredients were mixed in mechanically revolving concrete mixture for about two to three minutes until homogenous mixture was formed. After casting, samples were covered with plastic sheet to avoid the loss of moisture. All specimens were demolded $24 \pm 1$ hours after casting. Samples were then cured in lime saturated water up to for 28 days of concrete age. After 28 days of curing, concrete cylindrical specimens were divided into two groups. One third of the samples from 
each group were surface coated with bitumen and remaining were kept uncoated. These groups were designated as 1) Coated and 2) Uncoated. Reinforced concrete prisms were separated into three groups designated as 1) Cracked-uncoated, 2) Un-cracked-uncoated and 3) Un-cracked-coated. Out of these specimens, 36 were cracked under a pre-measured load while the other 54 were kept un-cracked. Half of these un-cracked beams were coated with bitumen layer. Cracking load was measured as the load required initiating cracks in the given reinforced concrete beam.

\subsection{Exposure Conditions}

After 28 days of curing and initial weighing, the samples were immersed in sodium sulfate solution of different concentrations. Two different concentrations ( $1 \%$ and $5 \%$ ) of $\mathrm{Na}_{2} \mathrm{SO}_{4}$ solution were used in the experimental program. Half of the un-coated cylindrical samples were immersed in $1 \% \mathrm{Na}_{2} \mathrm{SO}_{4}$ solution and other half in $5 \% \mathrm{Na}_{2} \mathrm{SO}_{4}$ solution. All of the bitumen coated cylinder specimens were kept in $5 \% \mathrm{Na}_{2} \mathrm{SO}_{4}$ solution. Reinforced concrete beam samples from Cracked-uncoated and un-cracked-un coated groups were divided in equal numbers. Half samples from each group were immersed in $1 \% \mathrm{Na}_{2} \mathrm{SO}_{4}$ solution and other half in $5 \% \mathrm{Na}_{2} \mathrm{SO}_{4}$ solution. All of the uncracked-coated reinforced beams were immersed in $5 \% \mathrm{Na}_{2} \mathrm{SO}_{4}$ solution. Level of solution was observed regularly and replaced biweekly.

\subsection{Mechanical Testing}

Compressive and flexural strength test were performed on all samples according to the provisions of ASTM C39 and ASTM C78, respectively. Compression testing was done at 7, 14, 28, 56, 90 and 120 days after immersion in sodium sulfate solution. Samples were taken out from solution tested in moist condition. Flexure strength test was performed at 14, 28, 56, 90, 120 and 150 days of sodium sulfate exposure. Third-point flexural strength test was carried out at the ASTM recommended rate of loading.

\subsection{Physical Inspection}

Physical inspection of specimens was carried out at same time as mechanical testing. Depth of efflorescence and change in mass of all the specimens were recorded simultaneously. Results observed are presented and discussed in section 3. Change in mass of specimens was calculated as:

$$
\operatorname{Mass} \text { Change }(\%)=\frac{\left(m_{i}-m_{f}\right)}{m_{i}} \times 100
$$

Where

$m_{i}=$ average initial mass of concrete specimens before immersion.

$m_{f}=$ average final mass of concrete specimens after immersion at test time.

\section{Results and Discussion}

\subsection{Physical Inspection}

Physical appearance of the plain concrete cylinders and reinforced concrete prisms aftre 120 days of exposure to $1 \%$ and $5 \%$ sodium sulfate solutions are shown in figure 1. The comparison of efflourescence height in different samples is presented in figure 2 . It is observed that the height of efflourescence for concrete cylinders immersed in $5 \% \mathrm{Na}_{2} \mathrm{SO}_{4}$ solution is significanlty greater than those immersed in $1 \% \mathrm{Na}_{2} \mathrm{SO}_{4}$ solution. An increased amount of water soluble sulfate ions give rise to carbonation of ettringite resulting in increased hight of efflourescence [28]. The surface coated cylinders showed no significant sign of efflourescence because the bitumen layer prevented the ingress of sulfates in the specimen however peeling of bitumen layer was observed in one of the specimen.

\subsection{Mass Change}

The percentage change in mass of all concrete cylindrical specimens is shown in figure 3. A substantial gain in mass of all specimens is observed up to 56 days of exposure to sodium sulfate solution. After 56 days, reverse trend is observed, i.e., the mass of all specimens started decreasing, however the final mass of all the specimens after 120 days of immersion was still higher than initial mass before immersion. The highest variations (either increase during first 56 days or decrease afterwards) were observed for un-coated specimens immersed in 5\% sodium sulfate solution. Least change in mass after 120 days of exposure was observed for bitumen coated specimens. The gain in mass during first 56 day can be attributed partially to the formation of hydration products and partially to the uptake of sulfates by specimens over the course of time. After 56 days of immersion in sulfate solution, the degradation of samples due to initiation of surface scaling is thought to cause reduction in mass of specimens during this period. Suleiman, A.R., Soliman, A.M. and Nehdi, M.L. have reported similar findings for various surface treated samples [29]. 
Table 1. Physical properties of coarse and fine aggregates

\begin{tabular}{|c|c|c|c|c|c|}
\hline Ingredient & $\begin{array}{c}\text { Specific } \\
\text { gravity }\end{array}$ & $\begin{array}{c}\text { Water Absorption } \\
(\mathbf{\%})\end{array}$ & $\begin{array}{c}\text { Bulk density } \\
\left(\mathbf{k g} / \mathbf{m}^{\mathbf{3}}\right)\end{array}$ & $\begin{array}{c}\text { Fineness } \\
\text { modulus }\end{array}$ & $\begin{array}{c}\text { Los Angeles } \\
\text { Abrasion } \%\end{array}$ \\
\hline Coarse aggregate & 2.72 & 1.09 & 1612.56 & 6.5 & 21.6 \\
\hline Fine aggregate & 2.34 & 1.68 & 1431.25 & 2.15 & - \\
\hline
\end{tabular}

Table 2. Mix design quantities for $0.1 \mathrm{~m}^{3}$ of concrete

\begin{tabular}{|c|c|c|}
\hline S/No. & Ingredient & Quantity \\
\hline 1 & Water $(\mathrm{kg})$ & 21.68 \\
\hline 2 & Cement $(\mathrm{kg})$ & 45.87 \\
\hline 3 & Coarse Aggregate $(\mathrm{kg})$ & 86.39 \\
\hline 4 & Fine Aggregate $(\mathrm{kg})$ & 96.24 \\
\hline 5 & Water Reducing Agent $(\mathrm{ml})$ & 285 \\
\hline
\end{tabular}

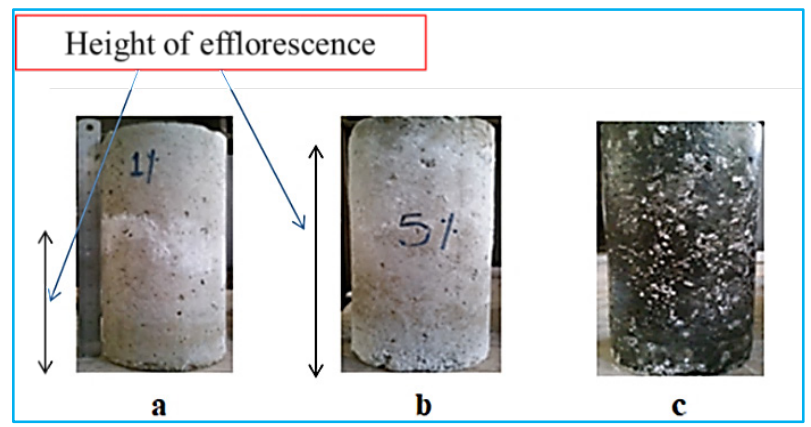

Figure 1. Visual inspection of concrete cylinders (a) uncoated immersed in $1 \% \mathrm{Na}_{2} \mathrm{SO}_{4}$ (b) uncoated immersed in $5 \% \mathrm{Na}_{2} \mathrm{SO}_{4}$ (c) coated with bitumen immersed in $5 \% \mathrm{Na}_{2} \mathrm{SO}_{4}$.

\subsection{Compressive Strength}

The results of compressive strength test after different exposure periods are presented in figure 4. A continuous increase in compressive strength of uncoated concrete specimens was observed up to 56 days of exposure to both $1 \%$ and $5 \%$ concentration $\mathrm{Na}_{2} \mathrm{SO}_{4}$ solutions. For instance, an increase in compressive strength by $5 \%, 9 \%, 11 \%$ and $22 \%$ was observed at 7, 14, 28 and 56 days of immersion, respectively, for $1 \%$ of sodium sulfate solution compared to that of the control specimen. The increase in compressive strength may be credited to the pore filling effect brought about by ettringite formation. Hence, the increase in the density accommpanied by the increase in compressive strength occurs. Similar results were observed by other researchers [30-32]. However, after 56 days of exposure, the continuous formation of expansive poducts resulted in pressure exerted by these products i. e. ettringite leading to formation of microcracks in concrete matrix. These cracks ultimately resulted in reduced compressive strength $[33,34]$. Another contributing factor reported in literature is the weakening of interfacial transition zone due to precipitation of ettringite in this zone [35]. No significant reduction in the compressive strength of bitumen coated specimens was observed. It remained almost uniform throughout the exposure period. Due to bitumen coating, the sulfates from external source could not enter concrete matrix which resulted in prevention of the formation of ettringite. These results proved the effectiveness of bitumen coating in preventing the deleterious effects of sulfate attack.

\subsection{Flexural Strength}

The flexural strength of all samples was measured by third-point loading method. The results are illustrated in figure 5. At exposure period of 14 days, flexural strength of uncracked concrete specimens immersed in 5\% sodium sulfate solution was $9 \%$ more than the uncracked concrete specimens immersed in $1 \%$ sodium sulfate solution. Approximately, $3 \%, 13 \%$ and $22 \%$ increase in flexural strength was observed for $5 \%$ concentration of $\mathrm{Na}_{2} \mathrm{SO}_{4}$ at 56, 90 and 120 days respectively, when compared to corresponding strength increases in $1 \% \mathrm{Na}_{2} \mathrm{SO}_{4}$ solution. This trend can be attributed to the filling of pores with salt crystals. Maximum increase in flexural strength was observed at 90 days of exposure. After 90 days, a decreasing trend in flexural strength was observed. Approximately, $26 \%$ and $20 \%$ decrease in flexural strength of uncracked prism specimens was found for $1 \%$ and 5\% concentration of sulfate, respectively, compared to flexural strength recorded at 90 days exposure period. This decreasing trend may be attributed to formation of micro cracks in concrete matrix as a result of tensile stresses developed due to expansion. Similar trend of change in flexural strength was observed for $1 \%$ and $5 \%$ cracked and bitumen coated specimens. 


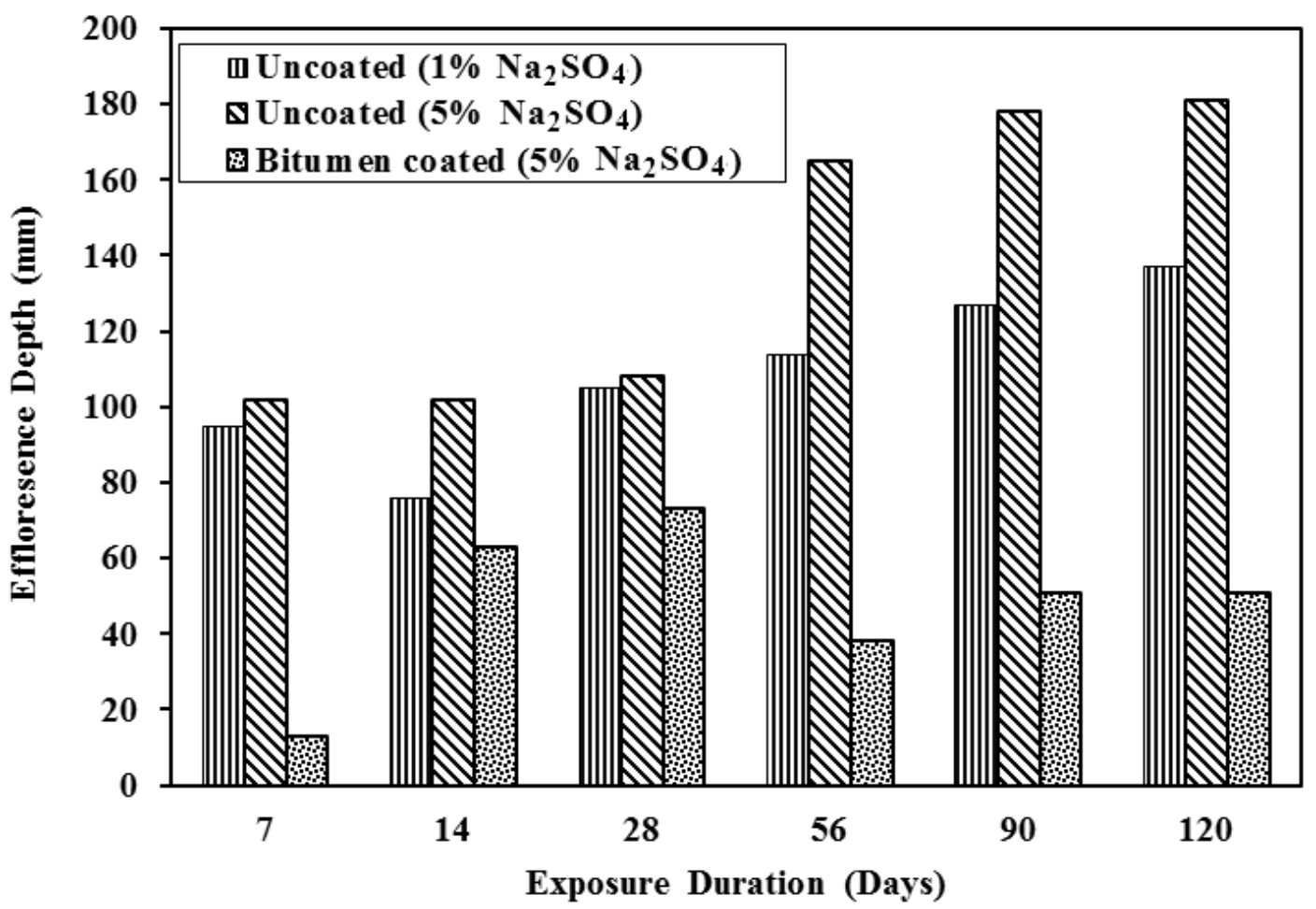

Figure 2. Height of efflorescence in concrete cylinders

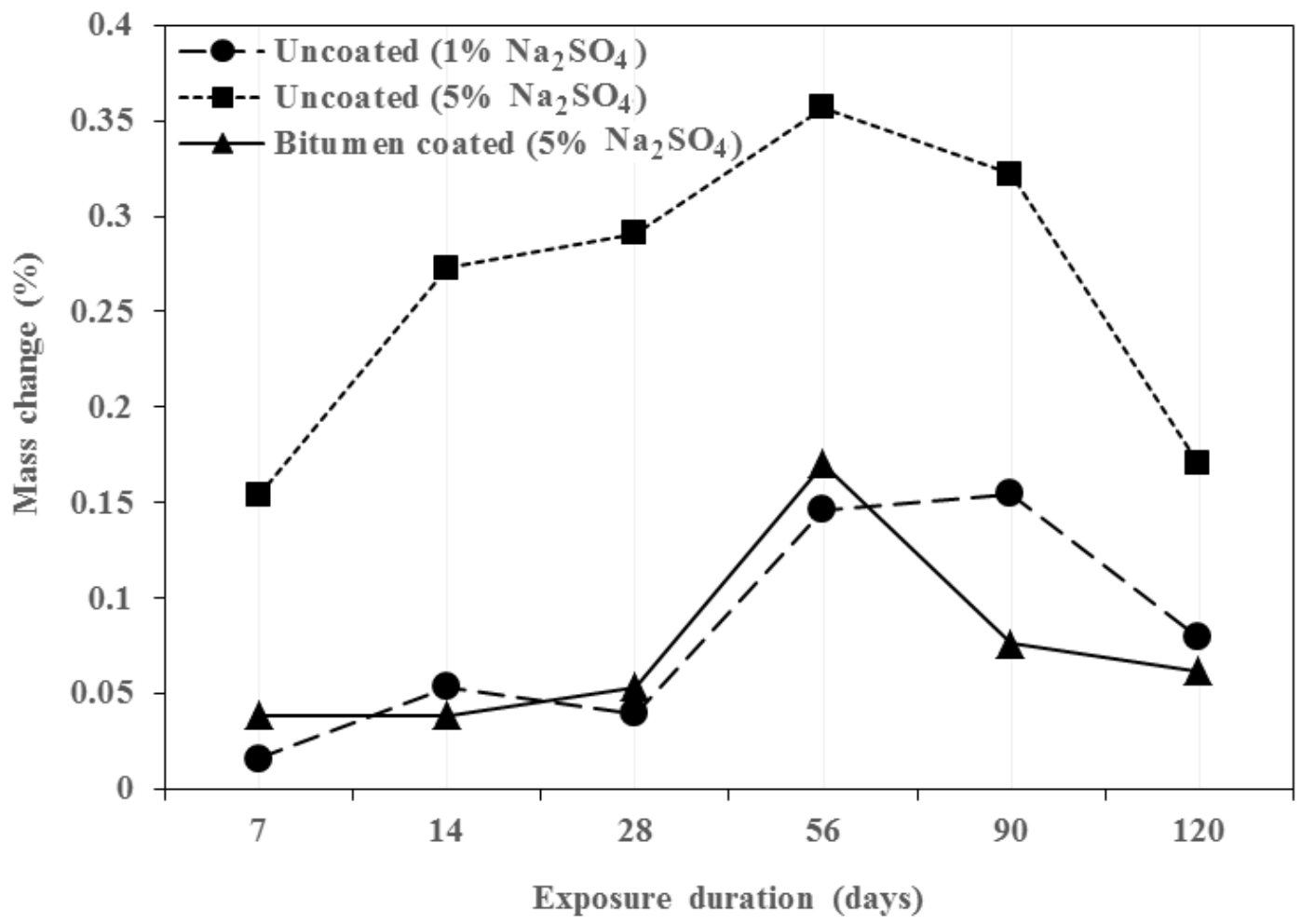

Figure 3. Change in mass of concrete cylinders exposed to sulfate solution 


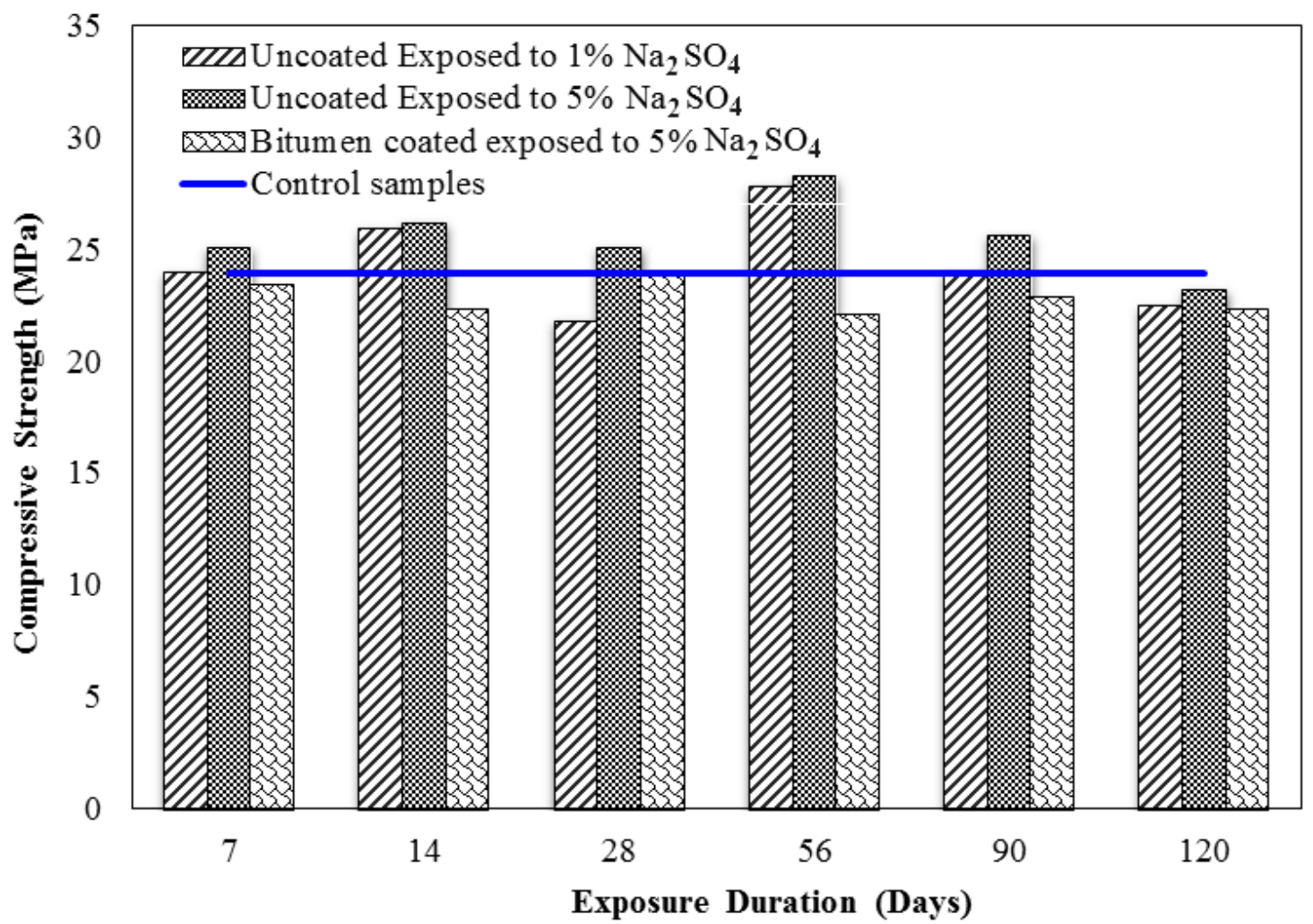

Figure 4. Compressive strength of concrete cylinders

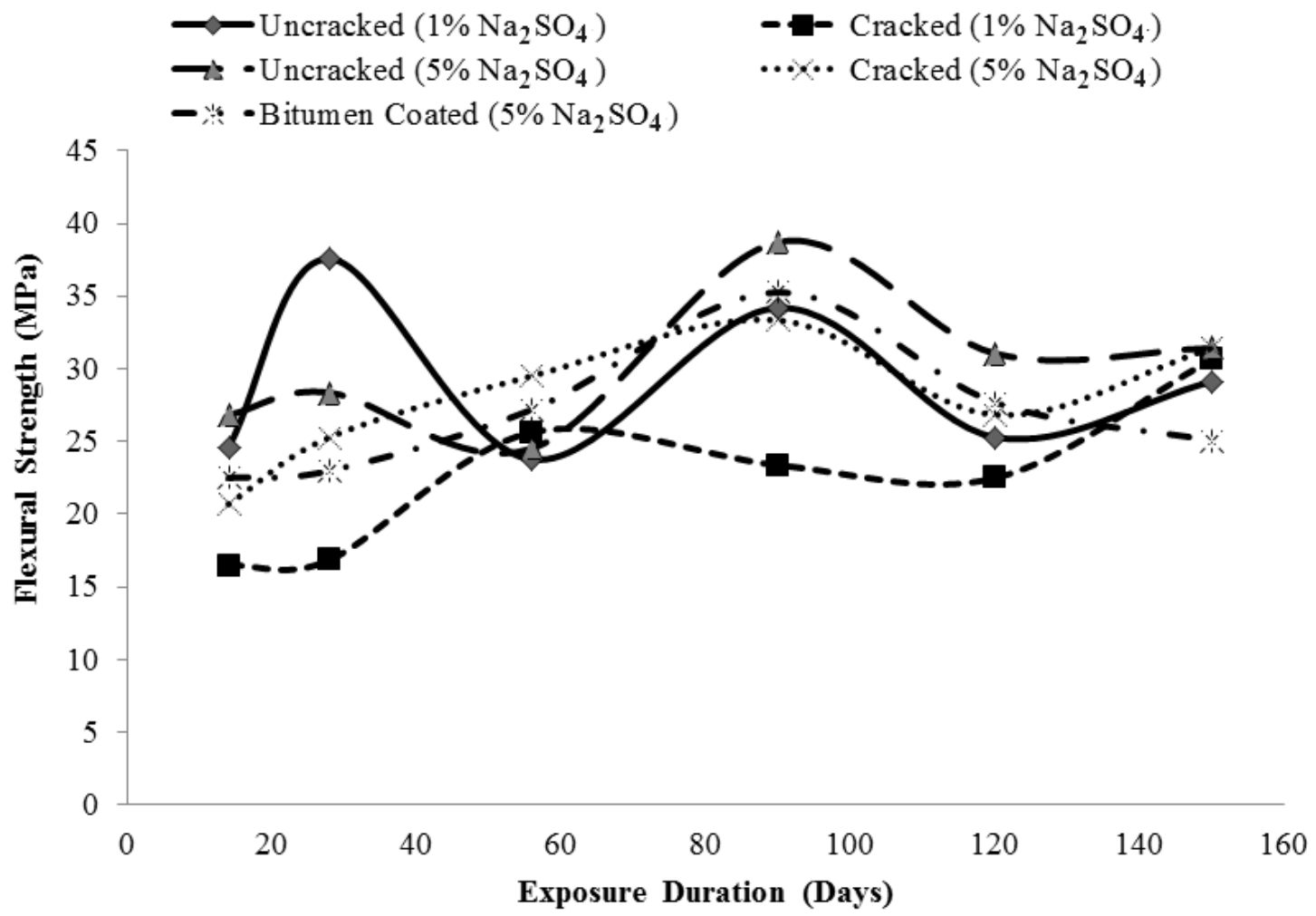

Figure 5. Flexural Strength reinforced concrete beams 


\section{Conclusions}

The effect of sulfate attack on plain concrete cylinders and reinforced concrete beam has been investigated in this research work. It can be concluded from the experimental results that:

- The increase in concentration of sulfates has a damaging effect on concrete specimens, both physically and mechanically.

- Deterioration in concrete due to sulfate ingress starts after 56 days of exposure to sulfate environment which is evident from mass loss and compressive strength test results, past this age.

- The cracked concrete members are more susceptible to sulfate attack than uncracked members due to easy access of sulfate ions inside the member.

- Surface coating of concrete members with bitumen is an effective method to mitigate the deleterious effects of external sulfate attack

\section{REFERENCES}

[1] J. Marchand, I.O., Jan P. Skalny: 'Sulfate Attack on Concrete' (CRC Press, 2019. 2019)

[2] Liu, Z., Hu, W., Hou, L., and Deng, D.: 'Effect of carbonation on physical sulfate attack on concrete by $\mathrm{Na}_{2} \mathrm{SO}_{4}$ ', Construction and Building Materials, 2018, 193, pp. $211-220$

[3] Neville, A.: 'Concrete: Neville's Insights and Issues' (Thomas Telford Ltd., 2006. 2006)

[4] Piasta, W.: 'Analysis of carbonate and sulphate attack on concrete structures', Engineering Failure Analysis, 2017, 79 , pp. 606-614

[5] Mehta, P.K.M., Paulo. J. M. : 'Concrete: Microstructure, Properties, and Materials' (McGraw Hill Education, 2014, 4th edn. 2014)

[6] Min, H., Sui, L., Xing, F., Tian, H., and Zhou, Y.: 'An effective transport model of sulfate attack in concrete', Construction and Building Materials, 2019, 216, pp. $365-378$

[7] Tian, H., Zhou, Y., Sui, L., and Xing, F.: 'Evolution of the sulfate ion transport-deterioration process in concrete', Anti-Corrosion Methods and Materials, 2016, 63, (3), pp. 196-204

[8] Zhang, W., Min, H., Gu, X., Xi, Y., and Xing, Y.: 'Mesoscale model for thermal conductivity of concrete', Construction and Building Materials, 2015, 98, pp. 8-16

[9] Xie, F., Li, J., Zhao, G., Wang, C., Wang, Y., and Zhou, P.: 'Experimental investigations on the durability and degradation mechanism of cast-in-situ recycled aggregate concrete under chemical sulfate attack', Construction and Building Materials, 2021, 297, pp. 123771

[10] Haufe, J., and Vollpracht, A.: 'Tensile strength of concrete exposed to sulfate attack', Cement and Concrete Research, 2019, 116, pp. $81-88$

[11] Xiao, Q.H., Cao, Z.Y., Guan, X., Li, Q., and Liu, X.L.: 'Damage to recycled concrete with different aggregate substitution rates from the coupled action of freeze-thaw cycles and sulfate attack', Construction and Building Materials, 2019, 221, pp. 74-83

[12] Hussein, L., Amleh, L., Siad, H., and Lachemi, M.: 'Effect of very severe sulfate environment on bonded composite concrete system', Construction and Building Materials, 2018, 191, pp. 752-763

[13] Bassuoni, M.T., and Nehdi, M.L.: 'Durability of self-consolidating concrete to different exposure regimes of sodium sulfate attack', Materials and Structures, 2009, 42, (8), pp. 1039-1057

[14] Chen, J.-k., Jiang, M.-q., and Zhu, J.: 'Damage evolution in cement mortar due to erosion of sulphate', Corrosion Science, 2008, 50, (9), pp. 2478-2483

[15] Mangat, P.S., and El-Khatib, J.M.: 'Influence of initial curing on sulphate resistance of blended cement concrete', Cement and Concrete Research, 1992, 22, (6), pp. 1089-1100

[16] Scherer, G.W.: 'Stress from crystallization of salt', Cement and Concrete Research, 2004, 34, (9), pp. 1613-1624

[17] ASTM: 'ASTM C150 / C150M - Standard Specification for Portland Cement', in Editor (Ed.) ${ }^{\wedge}$ (Eds.): 'Book ASTM C150 / C150M - Standard Specification for Portland Cement' (ASTM International, 2020, edn.), pp.

[18] Diana, G., and Hooton, R.D.: 'Assessing Performance of Sulfate-Resistant Portland Cements', ACI Materials Journal, $116,(6)$

[19] Rajaram Dhole, M.D.A.T., Kevin J. Folliard, and Thano, D.: 'Chemical and Physical Sulfate Attack on Fly Ash Concrete Mixtures', ACI Materials Journal, 116, (4)

[20] Joshi, S., Goyal, S., Mukherjee, A., and Reddy, M.S. 'Protection of concrete structures under sulfate environments by using calcifying bacteria', Construction and Building Materials, 2019, 209, pp. 156-166

[21] Kunther, W., Lothenbach, B., and Scrivener, K.: 'Influence of bicarbonate ions on the deterioration of mortar bars in sulfate solutions', Cement and Concrete Research, 2013, 44, pp. 77-86

[22] Tayeh, B.A., Al Saffar, D.M., Aadi, A.S., and Almeshal, I.: 'Sulphate resistance of cement mortar contains glass powder', Journal of King Saud University - Engineering Sciences, 2020, 32, (8), pp. 495-500

[23] Dang, Y., Xie, N., Kessel, A., McVey, E., Pace, A., and Shi, X.: 'Accelerated laboratory evaluation of surface treatments for protecting concrete bridge decks from salt scaling', Construction and Building Materials, 2014, 55, pp. 128-135

[24] Moon, H.Y., Shin, D.G., and Choi, D.S.: 'Evaluation of the durability of mortar and concrete applied with inorganic coating material and surface treatment system', Construction and Building Materials, 2007, 21, (2), pp. 362-369

[25] Vipulanandan, C., and Liu, J.: 'Performance of 
polyurethane-coated concrete in sewer environment', Cement and Concrete Research, 2005, 35, (9), pp. $1754-1763$

[26] Zhang, H., Ji, T., Liu, H., and Su, S.: 'Improving the sulfate resistance of recycled aggregate concrete (RAC) by using surface-treated aggregate with sulfoaluminate cement (SAC)', Construction and Building Materials, 2021, 297, pp. 123535

[27] Pan, X., Shi, Z., Shi, C., Ling, T.-C., and Li, N.: 'A review on surface treatment for concrete - Part 2: Performance', Construction and Building Materials, 2017, 133, pp. 81-90

[28] Brocken, H., and Nijland, T.G.: 'White efflorescence on brick masonry and concrete masonry blocks, with special emphasis on sulfate efflorescence on concrete blocks', Construction and Building Materials, 2004, 18, (5), pp. 315-323

[29] Suleiman, A.R., Soliman, A.M., and Nehdi, M.L.: 'Effect of surface treatment on durability of concrete exposed to physical sulfate attack', Construction and Building Materials, 2014, 73, pp. 674-681

[30] Al-Dulaijan, S.U.: 'Sulfate resistance of plain and blended cements exposed to magnesium sulfate solutions', Construction and Building Materials, 2007, 21, (8), pp. 1792-1802

[31] Naik, N.N., Jupe, A.C., Stock, S.R., Wilkinson, A.P., Lee, P.L., and Kurtis, K.E.: 'Sulfate attack monitored by microCT and EDXRD: Influence of cement type, water-to-cement ratio, and aggregate', Cement and Concrete Research, 2006, 36, (1), pp. 144-159

[32] Zhang, M., Chen, J., Lv, Y., Wang, D., and Ye, J.: 'Study on the expansion of concrete under attack of sulfate and sulfate-chloride ions', Construction and Building Materials, 2013, 39, pp. 26-32

[33] Flatt, R.J.: 'Salt damage in porous materials: how high supersaturations are generated', Journal of Crystal Growth, 2002, 242, (3), pp. 435-454

[34] Tsui, N., Flatt, R.J., and Scherer, G.W.: 'Crystallization damage by sodium sulfate', Journal of Cultural Heritage, 2003, 4, (2), pp. 109-115

[35] K.L. Scrivener, J.F.Y.: 'The Diagnosis of Chemical Deterioration of Concrete by Optical Microscopy' (CRC Press, 1997, Ist edn. 1997) 